Public Men and Public Universities:

State Schools in the Antebellum South

Charles Frederick Irons

Chapel Hill, NC.

B.A.. University of Virginia, 1997

A Thesis presented to the Graduate Faculty

of the University of Virginia in Candidacy for the Degree of

Master of Arts

Department of History

University of Virginia

A ugust 1999

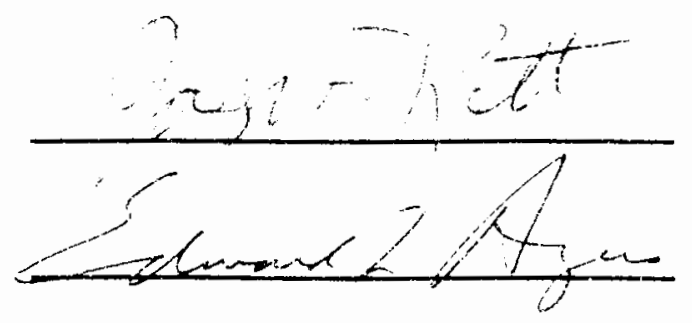




\section{Public Men and Public Universities: State Schools in the Antebellum South}

In the decades following the successful American bid for independence, the public men of the South-successful businessmen, planters, statesmen, and military figuresestablished public universities in order to cultivate indigenous leadership for their respective states. Their lack of academic credentials and experience in higher education did not deter these elite men, for they desired primarily to make leaders, not scholars. In North Carolina and Virginia, the two states examined in this paper, the prominent founders of the state universities demonstrated a long-term commitment to training a new generation of leaders by serving as trustees or visitors of the new schools. ${ }^{1}$ From these official positions, they initially controlled every part of the students' education, including what they learned in the classroom, what they did after hours, and what kind of recognition, if any, they received at graduation. Soon after the each school opened, however, the board members at each school transferred their control of student discipline to the faculty, whose proximity put them in a better position to maintain orderly behavior. Beginning in the late1820s, professors gained more control of the curriculum as well, for they commanded a body of increasingly specialized scientific knowledge that was foreign to most trustees. Board members willingly deferred to the faculty's disciplinary power and academic expertise because they were able to train leaders through other, more informal channels, such as annual balls, commencement ceremonies, and literary society events. The young men themselves seemed to prefer learning lessons from the trustees. Throughout the antebellum period, many students attended school with no intention of taking an academic degree; from 1825-1842, for example, a full two-thirds of students at

\footnotetext{
${ }^{1}$ UNC, chartered in 1789, did not receive its first student, Hinton James, until 1795. A Board of Trustees of forty men, most of whom had been involved in the founding, governed the school. A Board of Visitors ran UVa, which received its charter from the state in 1819 and opened in 1825 . "Trustees" and "Board Members" may be used inclusively to indicate the leadership of both schools.
} 
the University of Virginia stayed for only one year or less. ${ }^{2}$ In the 1820 s and 1830 s, then, professors transformed Chapel Hill and Charlottesville into sophisticated centers of knowledge, but students continued to look beyond them to men in the political centers in Raleigh and Richmond for a more practical introduction to public life.

A new awareness of the state as the fundamental political unit inspired elites across the South to charter public universities in the late eighteenth and early nineteenth centuries. Not only did the victors of the Revolution consider it unpatriotic to send their children abroad for an education, but they also perceived the need to train lawyers, judges, generals, businessmen, and statesmen a responsibility of the newly independent states. Legislators across the region rushed to establish colleges or universities; Georgia (1785), North Carolina (1789), Tennessee (1794), South Carolina (1801), and Louisiana (1805) founded schools in quick succession. ${ }^{3}$ Many Virginians considered William and Mary, chartered by royal decree in 1693, the functional equivalent of a state university, and they decided against founding another school. After all, William and Mary already fulfilled the two most important functions of the new state schools: it introduced young men to politically active alumni and gave the next generation of leaders an opportunity to build relationships with one another. ${ }^{4}$ Governor Drayton highlighted these two characteristics of a successful state school in his address to the South Carolina legislature in 1801. Such a school, he explained, should be "under proper directors and trustees,

\footnotetext{
2 Frederick Rudolph, Curriculum: A History of the American Undergraduate Course of Study Since 1636 (San Francisco: Jossey-Bass, 1978), pp. 86-87. Lewis Ashby Martin, III, "John A. G. Davis, Professor of Law, and the Faculty of the University of Virginia, 1830-1840," Master's Thesis, UVa, 1973, appendix VII. In the 1840-1841 session, Lewis reports that a full $60 \%$ of students (155/179) enrolled for only one class each session, a pace too slow to ever graduate.

${ }^{3}$ Edgar W. Knight, ed., A Documentary History of Education in the South Before 1860, vol. III (Chapel Hill: UNC Press, 1952), p. vi.

${ }^{4}$ Thomas Jefferson actually did try to convince the legislature to radically alter William and Mary and to make it an official state university in his 1779, "Bill for the General Diffusion of Knowledge." He hoped to transfer the sponsorship of the college from the Church of England to the State of Virginia and to add several professorships. In Notes on the State of Virginia, he wrote that "the plan [of William and Mary] is
} 
including as ex-officio members of the Executive and Judiciary." The trustees would serve as role models and guides, creating an environment in which "the friendships of young men would thence be promoted and strengthened throughout the State, and [South Carolina's] political union be much advanced thereby." ${ }_{5}$

The escalating sectional tensions of the nineteenth century underscored the statecentered mission of Southern state universities. Few Southerners trusted any school beyond the Mason and Dixon line to educate their sons in a manner consistent with state interests. A second wave of charters-Virginia (1819), Alabama (1820), Mississippi (1844), and Texas (1858)—reflected the South's growing commitment to educate from within. ${ }^{6}$ Not only did fewer Southerners venture North to school, but Northerners, always a minute presence, stopped attending Southern schools almost entirely. Between 1855 and 1860, only one out of almost 400 students graduating from the University of North Carolina (UNC) hailed from a non-slaveholding state, C. Stephens Croom of New York City. Only eight of more than 600 students at the University of Virginia (UVa) during those five years lived outside of the region. ${ }^{7}$ About two-thirds of the matriculates at each school came from in-state, with young men from the Southern frontier states of

proposed to be enlarged ... and extended to all the useful sciences." Thomas Jefferson, Notes on the State of Virginia, ed. with intro. by William Peden (New York: W. W. Norton, 1982), pp. 146-148, 289.

${ }^{5}$ Maximilian LaBorde, History of the South Carolina College from its Incorporation, Dec 19, 1801, to Dec 19, 1865, Including Sketches of its Presidents and Professors, (Charleston: Walker, Evans, and Cogswell, 1874), pp. 8, 9.

${ }^{6}$ Knight, Documentary History, vol. III, p. vi. The rate of westward expansion also helped to determine the second round of charters. With the exception of Virginia, none of these four were states in the postRevolutionary period. Alabama entered statehood on December 19, 1819; Mississippi on December 10, 1817; and Texas on December 29, 1945.

7 Ibid, 248-250. Kemp Battle, History of the University of North Carolina from Its Beginning to the Death of President Swain, vol I (Raleigh: Edwards and Broughton, 1907), pp. 806-813. Battle's Appendices make his History of the University an especially useful source. There are four useful tables: 1) List of graduates to 1868 , including after 1813 the names and professions of prominent non-graduates.

Hometowns included. (pp. 787-820) 2) List of Trustees 1789-1868 and of Executive Committee Members 1835-1868, including also the cost of buildings to 1868. Hometowns included. (pp. 821-827) 3) List of subscriptions made to start the University. (pp. 827-831) 4) Lists, compiled by Hon. Walter Murphy in 1899 , of public offices held by alumni. (pp. 832-836) University of Virginia, Catalogue of the University of Virginia: Session of 1857-58 and Session of 1859-60, (Richmond: Chas. Wynne, 1858 and 1860). 
Alabama and Mississippi making up most of the balance. Trustees designed their schools to produce state leaders, especially for their respective states. They succeeded, and at least a fifth of the graduates held state office, usually in the same state in which they received their education. ${ }^{8}$ Others exercised their leadership skills within their states as ministers, editors, or businessmen. A significant proportion of alumni also fought and died in the Confederate Army, a final testament to state and regional devotion.

Trustees imparted their lessons on state pride and leadership through personal interaction with the students. They appeared on grounds regularly, both for routine meetings and for gala events such as commencement day and the annual ball. The board members sent their children to the university, an action that brought the sons of the state's elite into close contact with one another and built networks of powerful families. Most importantly, however, the trustees supported student literary societies. As directors of their respective schools, the trustees and visitors ensured that the various societies always had a place to meet and included them in their plans for all public occasions. As individuals, the board members delivered speeches before the societies, gave them books for their libraries, and introduced them to other prominent men in the state. The students actively sought out this kind of mentoring; they invited the trustees to endless events, commissioned portraits of them, and actively emulated them. Within the literary society meetings, which functioned as little legislatures, they practiced the oratorical and debating skills that they observed in their role models. Students enthusiastically embraced the opportunity that state universities provided to connect with eminent men from their communities.

\footnotetext{
${ }^{8}$ Colin Burke, American Collegiate Populations: A Test of the Traditional View (New York: New York University Press, 1982), pp. 141-168, 203-206. Burke recorded the percentage of graduates from each school known to have participated in state government for three decades, the 1800 s (UNC only: $32.3 \%$ ), 1830s (UNC: $19.4 \%$, UVa: 20.1\%), and the 1850s (UNC 21.4\%, UVa $11.7 \%$ ).
} 
The faculty of Southern schools, in contrast to the patriotic trustees, prized knowledge, order, and, increasingly, evangelical Protestantism above civic pride. These values led professors to press for greater discipline, to expand the curricula set by the trustees, and to encourage a more central role for the church in university life. It did not take long in either Chapel Hill or Charlottesville for trustees to grant the faculty increased disciplinary authority. Soon after the first matriculates arrived, trustees realized that they could not adequately monitor student behavior and therefore granted faculty control of day-to-day discipline. Beginning in the late 1820 s, professors gained authority over material covered in the classroom as well. They taught new subjects, such as geology, agricultural chemistry, and mineralogy, in which the Visitors had little or no expertise. Unable to evaluate student performances in these unfamiliar subjects, the trustees ceded their responsibility for determining grades and granting degrees to the faculty. The faculty created a parallel educational track through their reforms of university life; they tried to create scholars in a well-regulated academic community, while trustees relied on the extracurriculum to forge leaders. Presented with these competing visions of education, students chose to emulate the famous men whom they met at literary society meetings and commencement ceremonies, not the stodgy professors who governed their classrooms.

This essay synthesizes several established theories about education in the antebellum South; few of its component parts are, of themselves, new. The assertion that Southern elites communicated specific values through the schools, for example, finds roots in the work of John Gould Fletcher and Edgar W. Knight. ${ }^{9}$ Colin Burke, for his part, confirmed that a significant percentage of Southern graduates went into public

\footnotetext{
9 John Gould Fletcher, "Education, Past and Present," I'll Take My Stand (Baton Rogue: LSU Press, 1930), pp. 92-121. Edgar W. Knight, "Southern Opposition to Northern Education," Educational Forum XIV, 1 (November 1949), pp. 47-58.
} 
service. ${ }^{10}$ In his history of undergraduate curricula, Frederick Rudolph discussed battles between trustees and faculty members over the content of university education. ${ }^{11}$ James Oakes and many others have insisted that slavery and progress, chattel and modernity were incompatible. His work helps make sense of the curious landscape of Orange County, North Carolina, which, in 1830, held both vast plantations and one of the nation's most sophisticated observatories. ${ }^{12}$ On a parallel track, Beth Schweiger and George Daniels have observed the professionalization of clergy and educators beginning in the late $1820 \mathrm{~s}^{13}$ Student literary societies have come alive in work by James McLachlan, who explained their central place in the antebellum extracurriculum. ${ }^{14}$ To all of this, the great university historians, Kemp Battle of UNC and Philip Alexander Bruce of UVa, provided invaluable context with their meticulous works, History of the University of North Carolina from its Beginning to the Death of President Swain, 17891868 and History of the University of Virginia 1819-1919: The Lengthened Shadow of One Man. ${ }^{15}$ This essay incorporates these disparate arguments into a new, coherent

10 Bibliographical information, footnote 8. Burke's painstaking statistical analysis confirms that Southern state Universities graduated fewer ministers (152) and more political leaders (154) than did Northern schools during the antebellum period. He does, however, make several assertions about Southern culture that are unsupported by his data. He blames the Southem schools for failing to create an urban elite, without recognizing that the Southerners possessed a highly articulated, if decentralized and rural, nexus of economic and political power. He also fails to notice the percentage of public men produced by UNC.

11 See footnote 2 for bibliographical information.

12James Oakes, The Ruling Race: A History of American Slaveholders (New York: Alfred A. Knopf, 1982). See also Eugene D. Genovese, The Slaveholders' Dilemma: Freedom and Progress in Southern Conservative Thought, 1820-1860 (Columbia: USC Press, 1992). Genovese, who originally stressed an anti-capitalist, anti-modern interpretation of the American South (Roll, Jordan, Roll, 1974), emphasized here how Southerners could believe in both slavery and progress

13 Beth Barton Schweiger, "The Transformation of Southern Religion: Clergy and Congregations in Virginia, 1830-1895," diss., University of Virginia, 1994. George H. Daniels, American Science in the Age of Jackson (New York: Columbia, 1968) and "The Process of Professionalization in American Science: The Emergent Period, 1820-1860," ISIS: Official Quarterly Journal of the History of Science Society, 58, 2 (Summer 1967), pp. 151-166.

14 James McLachlan, "The Choice of Hercules: American Student Societies in the Early 19th Century," The University in Society, vol. 1I: Europe, Scotland, and the United States from the 16th to the 20th Century, Lawrence Stone, ed. (Princeton: Princeton University Press, 1974), pp. 449-494.

${ }^{15}$ Battle, History of UNC. Philip Alexander Bruce, History of the University of Virginia, 1819-1919: The Lengthened Shadow of One Man, 5 vols. (New York: MacMillan Co., 1920). Only vols I-III used here. I 
framework. It distinguishes between the different educational goals of trustees and faculty members, explains the persistence of trustee influence in spite of faculty ascendancy in the classroom, and locates the mechanisms for trustee education firmly in the extracurriculum.

When UNC and UVa received their first students, in 1795 and 1825, respectively, the trustees controlled every part of the universities. Before the difficulty of maintaining student order and keeping pace with faculty expertise eroded some of their prerogatives, they had a hand in every facet of their university's development. With support from the state legislatures, they set the curricula, purchased the books, and designed the buildings. The trustees at UNC and the Visitors at UVa had liberal reins to craft a system through which they could shape young men into state leaders in every field: medicine, religion, education, warfare, and, especially, politics. North Carolinians first adopted this goal because of the republican obligation to provide for leadership for future generations, while Virginia's Visitors considered the fear of Northern Federalism an equally compelling motive for keeping quick minds at home. Despite these subtle differences in original intent, which vanished with the surging states' rights rhetoric of the 1830s, both North Carolina and Virginia trustees wanted to introduce young men to state politics, protect them from harmful intellectual influences, and prevent them from spending their education dollars abroad. In pursuit of these simple, state-oriented goals, the assembled judges, generals, planters, and statesmen designed first-class universities.

William Richardson Davie, the Revolutionary War hero and Father of the University of North Carolina clearly articulated the republican sentiment that motivated many North Carolina trustees to educate new leaders. He worried that, without a

have also used extensively John S. Patton, Jefferson, Cabell and the University of Virginia (New York: Neale Publishing, 1906) 
university, there would not be enough qualified young men to administer the needs of the new state and nation. This concern prompted him to propose a bill to charter the University in 1789. The preamble to this successful bill encapsulated Davie's desire to educate a ruling class: "In all well regulated governments it is the indispensable duty of every legislature to consult the happiness of a rising generation, and endeavor to fit them for an honorable discharge of the social duties of life."16 Davie's quest to train new leaders grew more out of a sense of civic obligation than of actual pride of place. In November of 1819 , he showed that his belief in education was not state-specific when he wrote from his new home in South Carolina to Joseph Caldwell, then president of UNC, and asked him to take a position at the University of South Carolina. ${ }^{17}$

Thomas Jefferson, the mastermind behind virtually every facet of the University of Virginia, attempted unsuccessfully to establish a university in the same burst of revolutionary civic-mindedness that had inspired Davie. ${ }^{18}$ He proposed a farsighted "Bill for the General Diffusion of Knowledge" in 1779, but the bill merely floundered about on the floor of the legislature until it passed in severely compromised form in 1796. Jefferson did not seriously advocate a new educational plan until after his term as third President of the new nation, from 1801 to 1809 . Presidential exposure to Northern

\footnotetext{
16 Taken from the preamble to his successful 1789 bill to charter the University in Battle, History of UNC, p. 6. In an 1801 letter, he made more explicit the connection between the estab!ishment of state universities and the success of the nation, asserting that "every man really attached to the liberties of his Country, every sincere republican" must heartily support the University. William R. Davie to Maj. John R. Eaton, 27 Dec 1801, in William Richardson Davie: A Memoir: James Sprunt Historical Monograph, no. 7, Kemp Battle, ed. with an introduction by J. G. de Roulhac Hamilton (Chapel Hill: UNC Press, 1907), p. 49.

17 Joseph Caldwell Papers, UNC-Southern Historical Collection, 1 November 1819.

18 In 1779, Jefferson proposed a "Bill for the General Diffusion of Knowledge," that provided for a threetiered educational system, including free common schools, a college in every district, and the conversion of William and Mary into a full-fledged university that would accept on scholarship one outstanding pupil from every district. The 1796 version was rendered impotent by an amendment that "the court of each county shall determine the year in which the alderman [district representatives responsible for the construction and operation of new schools] shall be appointed and until they so determine no election shall be held." No alderman were ever selected, nor any schools opened under this bill. Cornelius J. Heatwole, A History of Education in Virginia (New York: The MacMillan Company, 1916), pp. 101-102. Bruce, History of the University, vol. I, pp. 67-71.
} 
Federalism and dissatisfaction with the denominational focus of his alma mater,

William and Mary, made the Virginian again pursue the idea of a state university. He did not wait for state support and started construction on Central College in 1817.

Fortuitously, Jefferson served on the state's Rockfish Gap Commission, which recommended in 1818 that the Virginia legislature adopt his own unfinished Central College as the official University of Virginia, which the representatives did in the following year. 19 The institution that Jefferson and his friends laid out was more than an expression of civic obligation to provide state leadership. After eight years of factional national politics, he designed his University as an anecdote to Northern Federalism, which had its own academic thrones at Harvard and Yale. The authors of the Virginia and Kentucky resolutions, James Madison and Jefferson, each served on the first Board of Visitors, and they wanted to create in Charlottesville a distinctively Virginian, antiFederalist place. He confided his fears about "quondam federalism, now consolidation," to fellow visitor Joseph Cabell in 1825 , and reminded him that "It is our duty to guard against the dissemination of such principles among our [Virginia's] youth, and the diffusion of that poison." 20

In the 1820 s and 1830s, trustees at UNC and across the South joined Jefferson and the Visitors in translating sectional concerns — such as the Missouri Compromise (1820), John Marshall's judicial nationalism (chief justice 1801-1835), and the Nullification

\footnotetext{
19 "The First Stone of Central College, Virginia, is Laid, 1817," Knight, Documentary History, p. 136.

"Thomas Jefferson sends to the Speaker of the House of Delegates the Report of the "Board of Commissioners' of the University of Virginia, November 20, 1818," Knight, Documentary History, p. 162. "Report of the Rockfish Gap Commission Appointed to Fix the Site of the University of Virginia, 1818," Knight, Documentary History, pp. 162-178.

${ }^{20}$ Reprinted in University, of Virginia: Its History, Influence, Equipment and Characteristics with Biographical Sketches and Portraits of Founders, Benefactors, Officers and Alumni, vol. I, Paul Barringer, James Garnett, and Rosewell Page, eds. (New York: Lewis Publishing Co., 1904), p. 305. In addition to writing a useful history of the University and reprinting several important documents from the University's early history, the editors assembled a very considerable collection of biographies on influential Cavaliers. There are several hundred-word biographies for 29 "founders, visitors, and benefactors" and 212 "officers and alumni."
} 
Crisis (1832) — into a desire to educate their children at home. ${ }^{21}$ Jefferson spoke early and forcefully: "If our legislature does not heartily push our University," he challenged in 1820, "we must send our children for education to Kentucky or Cambridge. The latter will return them to us fanatics and Tories, the former will keep them."22 The Visitors supported their Rector and lamented the "heavy tribute [they were] annually paying to other states and countries for the article of education," while dreaming of "the desirable moment when the youth of their country may find at home those resources of instruction."23 From the beginning, the founders of the University of Virginia focused on the specific task of educating Virginia's youth to take charge of Virginia's political destiny.

UNC's trustees had abandoned Davie's republican rhetoric and adopted a more Jeffersonian assertion of state pride by 1830 . In that year, trustee Thomas Ruffin, then justice on the North Carolina Supreme Court, bragged to the legislature that alumni who had moved out of the state "thank God that though they do not live in North Carolina, they were born on her soil and were educated under her patronage." 24 In a circular to parents in 1837 , the Executive Committee similarly boasted "that our young men are not compelled to go abroad, to obtain an education in all respects equal to that given in the best Institutions in the United States; and that it is not necessary to make any sacrifice

\footnotetext{
${ }^{21}$ William G. Shade, Democratizing the Old Dominion: Virginia and the Second Party System, 1824-1861 (Charlottesville: UVa Press, 1996), pp. 224-261 (Chapter 7). Shade explains how national events forced Virginians to rally around "the Doctrines of " 98 " in the 1820s and 1830 s.

22 Jefferson to Joseph C. Cabell, 22 Jan 1820, in Knight, Documentary History, p. 200.

${ }^{23}$ UVa, Rector and Board of Visitors, Minutes, vol. II, 1817-1836, 2 October 1820 (first portion of quotation) and 4 October 1819 (second portion quotation).

24 University of North Carolina, Minutes: Board of Trustees, 24 Nov 1830, UNC-Southern Historical Collection.
} 
upon the altar of State pride, in order to remain at home."25 Sectional competition reinforced trustees' pride in their state and their intent to educate capable state leaders.

North Carolina and Virginia state legislators believed in the projects proposed by elites from within their midst, and they supported the state universities. Each legislature, however, adopted very different financial strategies. Virginians granted their University generous and predictable levels of funding, \$15,000 a year from the state's Literary Fund in addition to periodic grants for special purposes. ${ }^{26}$ UNC received just as much money from the state, but in a curious form of bequest that required extensive labors on the part of the trustees to make use of their funding. The state of North Carolina placed the trustees of the University in charge of all of the property confiscated during the Revolutionary War and all of the property unclaimed by veterans of that conflict (for veterans received a certain amount of acreage for meritorious service). For over fifty years after the founding, North Carolina's trustees worked to translate these extensive land holdings into cash, resulting in an estimated total of $\$ 300,000$ for the school. ${ }^{27}$

Since trustees had so much difficulty accessing these funds, the university teetered on the verge of bankruptcy several times in its early days. ${ }^{28}$ When the trustees decided to raise money through a lottery in 1801 to resolve one of these early crises, the state legislature sympathetically approved their plan within nine days. Benjamin Williams, Governor and ex officio president of the Board of Trustees undoubtedly facilitated this fantastic

\footnotetext{
25 John Caldwell Collection, Trustee circular, 15 April 1837, UNC-Southem Historical Collection.

26 Cornelius J. Heatwole, A History of Education in Virginia (New York: MacMillan Co., 1916), p. 185.

27 UNC, Minutes: Board of Trustees, 24 Nov 1830.

28 Archibald D. Murphey, "Report on Education, submitted to the Legislature of North Carolina, 1817," reprinted in Publications of the North Carolina Historical Commission: The Papers of Archibald D. Murphey, vol. II (Raleigh: E. M. Uzzell and Co., 1914), pp. 63-83. On p. 73, Murphey complained, "When this institution was first founded, it was fondly hoped that it would be cherished by the Legislature: But unfortunately the nature of the funds with which it was endowed, in a short time rendered it odious to some, and cooled the ardor of others. ..." resulting in temporary cash shortages.
} 
turnaround time. ${ }^{29}$ Though methods of collection differed from university to university, the trustees of each institution enjoyed the financial support of their friends in Richmond and Raleigh.

The trustees, led at UNC by Davie and at UVa by Jefferson, created the curriculum and purchased books for the library. The core requirements at each school reflected the board members' desire to train students in oratory, for both schools insisted on training Latin and Greek literature. Davie complained to Joseph Caldwell that to grant "a degree upon such a person who understood neither Latin or Greek does not appear to be proper," and Jefferson echoed that no student should graduate unless he was "able to read the highest classics . . . with ease." 30 Both founders believed that classical training sharpened students' rhetorical skills by exposing them to examples of ancient rhetoric and giving them a storehouse of material on which to build allusions. At UNC, classics became an optional part of a simple four-year curriculum. Students could pursue either a full degree, with knowledge of both Latin and Greek, or a Bachelor of Science, with proficiency only in English and in the sciences. ${ }^{31}$ Jefferson led UVa on a more radical course and allowed students to enroll for any amount of time in any combination of the University's eight schools. ${ }^{32}$ Students attended classes until they demonstrated mastery of the material, then they received a certificate of graduation from the specific school.

29 UNC, Trustee Minutes, 9 Dec 1801, 18 Dec 1801.

30 William R. Davie to Joseph Caldwell, 26 Feb 1797, in Davie: A Memoir, p. 34. "Joumal of the Proceedings of a Convention of Literary and Scientific Gentlemen, held in the Common Council Chamber of the City of New York. October, 1830," American Quarterly Review, XVIII (June 1831), p. 308. After Jefferson's death (1826) and before 1837, the Visitors replaced this classical language requirement with an examination of the "ability to write the English language correctly." UVa, Catalogue of the University of Virginia: Session of 1837-38 (Charlottesville: Tompkins and Noel, 1838), p. 17.

${ }^{31}$ UNC, Trustee Minutes, 6 Feb 1795. As agreed on by the Trustees in 1795, students attended recitations in Latin and Greek, interspersed with English grammar, Arithmetic Bookkeeping, and Geography, for the first two years. During their final two years, students left the classics behind and studied Geometry, Algebra, Astronomy, Natural and Moral Philosophy, Civic Govermment, History, and Belles Lettres.

32 Ancient Languages, Modem Languages, Mathematics, Natural Philosophy, Chemistry, Moral Philosophy, Medicine, and Law. 
Only with the creation of a Masters of Arts degree in 1831 could students receive a degree that represented work in multiple schools, the functional equivalent of a Bachelor of Arts. ${ }^{33}$ Davie and Jefferson, chief among the first trustees, each also exercised considerable autonomy in the selection of books for the university library. The trustees encouraged Davie in 1795 to buy books "as he may think proper" to fill the shelves. ${ }^{34}$ Jefferson, for his part, personally chose over four thousand volumes to serve as the foundation of Virginia's library. ${ }^{35}$ Before they even hired the first teacher, trustees had decided what students would do in the classroom.

Board members also planned their schools' physical plants. The Board of Visitors at UVa spent almost \$200, 000 dollars to implement Jefferson's architectural vision for the university, making the so-called "academical village" the most expensive campus in the country. ${ }^{36}$ In his innovative college design, Jefferson had grouped the library, professors' residences, and student rooms around a central "Lawn," all in grand neoclassical style. North Carolina trustees could not match such a tremendous capital investment, nor did they attempt to be as systematic in their creation of an architectural monument. Kemp Battle estimated that they paid out only about $\$ 28,000$ for construction over the first twenty years. ${ }^{37}$ Trustees themselves contributed money to several building projects; twelve of the fifteen donors who gave over $\$ 200$ for the

\footnotetext{
${ }^{33}$ Charles C. Wall, Jr., "Students and Student Life at the University of Virginia, 1825 to 1861 ," diss. University of Virginia, 1978, pp. 10-11.

${ }^{34}$ UNC, Trustee Minutes, 24 Jan 1795.

${ }^{35}$ Catalogue of the Library of the University of Virginia, Arranged Alphabetically, (Charlottesville: Gilmer, Davis, \& Co., 1828), passim. Harry Clemons, The University of Virginia Library, 1825-1950. Story of a Jeffersonian Foundation (Charlottesville: University of Virginia Press, 1954). Jefferson purchased over 900 books in Latin or Greek, over $20 \%$ of the total. Catherine Penniman Storie, "The American College Society Library and the College Library," College and Research Libraries, June 1945. This was about four times the number of books present in UNC's library on opening day.

${ }^{36}$ Heatwole, A History of Education, p. 64. A great many books have been published on Jefferson's Lawn as an architectural space. The most recent and insightful work is Thomas Jefferson's Academical Village: The Creation of an Architectural Masterpiece, ed. Richard Guy Wilson (Charlottesville: UVa Press, 1993).
} 
construction of the South building (1809-1811) were board members. ${ }^{38}$ Though they did spend a December 1793 meeting discussing ways to develop "ornamental grounds" and gave of their own money, UNC trustees did not spend as much time on building projects. ${ }^{39}$ Board members in Chapel Hill and Charlottesville exercised their prerogatives to spend more or less money on dorms and classrooms.

When the Universities of North Carolina and Virginia opened their doors, then, trustees held indisputable command. They had chosen the locations for their schools, designed the buildings, stocked the libraries, and set the curricula. Almost immediately, however, the faculty began to fill many of the roles that trustees had assumed for themselves. They disciplined students, chose what books to purchase, taught new subjects, and demanded more classroom equipment. However, as the trustees abandoned classroom and dorm life to faculty control, they maintained their hold on the extracurriculum and ensured that students would continue to receive an appropriate education in Southern public life. Students certainly perceived their time in the literary and debating societies as an explicit kind of political education. James K. Polk, the eleventh President of the United States and a UNC graduate, reminisced from the Executive Mansion in 1847: "I remember with pleasure my association with "our common and hallowed fraternity - the Dialectic Society,' and though nearly twenty-nine years have elapsed, since I closed my connection with it, I am deeply sensible of the great valuation of the instruction that I received by attending its exercises." 40 Students learned their lessons well. By 1899, 411 out of 2,828 graduates of UNC had served in the North

\footnotetext{
37 Battle, History of $U N C$, p. 826.

38 Ibid., pp. 821-825, 830 (Appendices).

39 UNC, Trustee Minutes, 12 December 1793.

40 James K. Polk to Dialect Society, 15 March 1847. From the Student Organizations and Activities: Dialectic Society Records in University Archives, Wilson Library, UNC-Chapel Hill.
} 
Carolina State Legislature. ${ }^{41}$ The numbers for Virginia did not lag far behind; twenty of the 152 Virginians enrolled at UVa during the session of 1839-1840 joined the State Legislature during their lifetime. ${ }^{42}$ Students flocked to their state universities as centers of state leadership, making them among the most successful universities of the midnineteenth century. In 1857, UNC and UVa ranked as the second and third most populous colleges in the nation, trailing only Yale. ${ }^{43}$

The trustees and the faculty members hailed from demographically distinctive backgrounds and sought to impart different kinds of knowledge to the students. The trustees and board members almost uniformly claimed native status, while the faculty members hailed from a much more heterogeneous background. The trustees moved easily through their states, proceeded by great reputations. Most owned plantations with substantial numbers of slaves, and all exuded success and respectability. Professors, on the other hand, often struggled to acclimate themselves to a strange new country or region, since many of them came from Europe or from the North. Furthermore, the faculty more openly expressed their commitment to Evangelical Christianity. While the founders of each institution received charges of infidelity, professors consistently

\footnotetext{
${ }^{41}$ Information from Joan Pendergraph, Records Department, UNC Alumni Association. According to the Alumni Association's database, 2,828 students took degrees from UNC-Chapel Hill before 1900, and 6,644 attended school. The percentage of those serving in the state legislature looms even larger when one considers that graduates typically waited for at least a decade before being elected to the legislature and that UNC lost so many of its sons to the Civil War.
}

42 Battle, History of UNC, p. 835 (Hon. Walter Murphy's list of alumni in public offices). 108 alumni served in the state legislatures of other states, only seven of whom served outside of the slave South. I checked the name of every Virginian in the University Catalogue of 1839-40 against an index of Virginia Legislators. 20/152 definitely served in the state legislature, possibly more. Ralph Wooster has shown that an overwhelming percentage of state legislators in older states, such Virginia and North Carolina were born in that state: VA: $1850-93.1 \%, 1860-95.4 \%$. NC: $1850-97.9 \%, 1860-94.3 \%$. Such a proportion of native officeholders made building connections within the state crucial. Wooster, Politicians, Planters, and Plain Folk: Courthouse and Statehouse in the Upper South, 1850-1860 (Knoxville: University of Tennessee Press, 1975), Appendix: Table 4.

43 American Almanac and Repository of Useful Knowledge for 1860 (Boston: Crosby, Nichols, and Co., 1860), pp. 204-205 in Robert F. Brabham, "Search for a Purpose: The University of North Carolina, 18751891," Master's Thesis, UNC, 1977. Yale enrolled 502 students, UNC 456, and UVa 417. 
advocated a more central role for religion. Some students united with the faculty over the issue of Evangelical Christianity, but most young men allied themselves instead with the trustees, whom they deemed their social peers.

From their inception, the trustee boards of each school held men of the very highest social rank. At the University of Virginia, the Governor appointed seven men to the first Board of Visitors: two ex-Presidents, a General from the War of 1812, and a smattering of legislators. A profile of one of these men, Joseph C. Cabell, underscores their extraordinary commitment to their native state. Cabell served for over thirty years in the state legislature, both as a senator and as a member of the House of Delegates, and was elected first president of the James River and Kanawha Canal Company. Despite his distinguished public service and renowned oratorical ability, however, Cabell repeatedly refused invitations to run for Congress, to travel abroad as an ambassador, or to serve on presidential cabinets. His reason always-_devotion to Virginia. ${ }^{44}$ Trustees from North Carolina displayed a similar commitment to their state. UNC's forty original trustees represented among the most accomplished men in the nation: the Governor, three signers of the Constitution, two Supreme Court judges, two district Judges, a bevy of United States Representatives and Senators, five future Governors, two Revolutionary War Generals, and many other prominent figures, all decorated for meritorious service to the state. ${ }^{45}$ By every measure and in every theater, except possibly religion, trustees led their respective states and represented them before the rest of the nation.

In contrast to the distinguished board members stood the professors. At Virginia, the contrast could not have been sharper; all five of the faculty members present on 7 March 1825, when the University held its first day of classes, had just arrived from

\footnotetext{
${ }^{44}$ Barringer, Garnett, and Page, University of Virginia, pp. 318-319. (biographical entry)

${ }^{45}$ Battle, History of UNC, pp. 4-5.
} 
England: Charles Bonnycastle, Robley Dunglison, George Long, Thomas Key, and George Blaetterman. ${ }^{46}$ This international faculty, gathered from England's finest institutions by Jefferson's close friend, Francis Gilmer, arrived in the Chesapeake with considerable intellectual acumen but few political connections. UNC opened with an even smaller group and an even more severe social gradient. The Reverend Doctor David Ker, a recent immigrant from Ireland and a Presbyterian minister, awaited the first student alone.

Ker was the first of many ordained faculty members on the UNC campus, including Elisha Mitchell, Joseph Caldwell, Robert Chapman, James Phillips, John Wheat, William Mercer Green, and William Hooper. The preponderance of clergymen provoked some North Carolinians to claim that Presbyterians dominated the faculty. In 1822, Joseph Caldwell responded the charge that he had given "an ascendant influence to presbyterianism in our college," and claimed that "not one man is likely to have his sentiments changed on the subject of denomination in religion while he is here." 47 While some worried about the faculty's religious zeal, more worried about William R. Davie's well-known skepticism. A critic nicknamed "Publius" criticized the trustees in the 23 December 1806 Wilmington Gazette for their heterodox faith. ${ }^{48}$ Little of the early criticism that UNC's trustees received for religious heterodoxy, however, found basis in fact. Students gathered twice daily for mandatory prayer in the school chapel, and the trustees even warned, "if any Student ... shall assert and endeavor to propagate among

\footnotetext{
46 Patton, Jefferson, Cabell, and the University, pp. 86-88.

47 From Joseph Caldwell to ?, Joseph Caldwell Papers \#127, Southern Historical Collection, Wilson Library, UNC-Chapel Hill.

48 Joseph Caldwell published an article defending the University against charges of atheism in the 30 December 1806 issue of the Wilmington Gazette, claiming to respond to a stinging editorial the week before. Loose Clipping, Joseph Caldwell Papers. See also Davie: A Memoir.
} 
the Students any principle subversive of the Christian religion, he shall be dismissed."49 William Mercer Green, a professor of Rhetoric and Logic, perhaps contributed to the impression that faculty members were especially devout, for he founded a new Episcopal church in 1842, the Chapel of the Cross. ${ }^{50}$

At UVa professors did, in fact, express greater devotion to Christianity than did the Visitors. Jefferson had refused to hire any clergy as professors in his new school, to require attendance at church or at daily prayer, to build a chapel, or to hire a chaplain. Professors led the initial assaults against this exceptionally rigorous separation of church and state. ${ }^{51}$ In 1829 , they joined with the students to fund a University Chaplain, because the Board of Visitors would not allocate money for religious purposes. ${ }^{52}$ The faculty also fought to provide the Chaplain a designated space in which to lead worship. While Chairman of the faculty in 1838 , Gessner Harrison, "the first of the professors that connected himself publicly with any Christian denomination," petitioned the Board of Visitors to build a chapel on grounds. ${ }^{53}$ The Board refused Harrison's petition that year and again in 1851.54 In 1848, Professor William McGuffey, the first clergyman on the faculty, started leading Morning Prayer every morning. The professors' work culminated in a revival among the students. In the late 1850 s, a pious mother exhorted her son: "I

\footnotetext{
49 Acts of the General Assembly and Ordinances of the Trustees, for the Organization and Government of the University of North Carolina (Chapel Hill: James Henderson, 1859), p. 28.

${ }^{50}$ The church actually changed its name from Church of the Atonement to Chapel of the Cross in 1848. The author worshipped in this church as a child. Battle, History of UNC, p. 479.

51 Jefferson and the first Visitors, indeed, did receive violent criticism for creating what some believed was a throne of iniquity. Francis Walker Gilmer wrote to Peter Minor in October 1817, "you have enemies in your camp, or about it, who represent you abroad as a set of gentlemen drilled \& disciplined in the school of infidelity, armed with all the materials of furty \& havoc ..." Francis Walker Gilmer to Peter Minor, 18 Oct 1817, Gilmer Family Papers, Special Collections, University of Virginia Library.
}

52 Patton, Jefferson, Cabell, and the University, p. 316.

53 Barringer, Garnett, and Page, University of Virginia, p. 130. UVa, BOV Minutes, vol. III 1837-1855, UVa Library, 5 July 1838. The Visitors did permit different ministers to lecture on a rotating basis in the Rotunda but resisted a separate religious building.

${ }^{54}$ UVa, BOV Minutes vol. III, 30 June 1851. UVa, BOV Minutes vol. III, 26 June 1852. 
am pleased to hear that you have a revival at Charlottesville and that some of the students have joined the church--it would be very happy news to me to hear that you had done so yourself." ${ }_{55}$ The students demonstrated the depth of their commitment to Christianity in a concrete way by establishing a Young Men's Christian Association in 1858. Harrison, Minor, Cabell, McGuffey, and Davis, led weekly Bible studies for these young men and contributed greatly to the success of the YMCA. ${ }^{56}$ As late as 1860, though---despite all of these evangelical victories-less than a third of Virginia students publicly professed religious belief. ${ }^{57}$ Faith was by no means a common denominator among students and faculty.

Class markers were easier to read than religious ones, and students immediately recognized the trustees as members of their own, affluent social class. With few exceptions, students at the Universities of North Carolina and Virginia claimed an elite lineage. Charles Wall's analysis of a random sample of students matriculating at UVa in both 1830 and 1850 revealed a predominance of slaveholders. According to his calculations, only one out of thirty families examined for 1830 did not own slaves, six of thirty-one in 1850. During this period, a modest 25 percent of Southern families owned slaves, but between 80 and 95 percent of UVa students came from slaveholding families. ${ }^{58}$ Wall argued that even the state students, a group of thirty-two students who received tuition from the state beginning in 1836, possessed considerable wealth. Edward St. George Cook, apparently a state student himself, informed his father in 1853 that, "many state students here are heirs to estates of considerable value," and that his

\footnotetext{
55 Quoted in Oakes, The Ruling Race, p. 99.

56 Bruce, History of the University, vol. III, p. 142.

57 Wall, "Student Life," p. 19, footnote 30. From a poll conducted by editors of The Virginia University Magazine in 1861.
} 
roommate "owns more than I expect to own for a long, long time to come." 59 UNC students came from similarly privileged backgrounds. So conspicuously did students there display their wealth that the trustees tried in 1837 to convince parents to send their children to school with less money. "The necessary expenses of a Student do not exceed two hundred and fifty dollars per annum," they assured them, "including clothes and pocket money." 60 Students at UVa owed even more; they paid \$238 that year, exclusive of "books \& stationary, clothing and pocket money."61 Most white Southerners did not earn that much in a year. ${ }^{62}$

Familial connections between trustees and students further solidified the relationships among elites. Many trustees sent their sons to the state universities, where they built friendships with other privileged youth and created a network of political possibilities. One student observed in 1840 of the University of Virginia that "The big men especially, are fond of sending their sons to it. We have a son of Chapman Johnson, of Mr. Wise, of Gov. Barbour, of Mr. Rives, \& c."63 Johnson, Wise, and Rives all served on the Board of Visitors. Scores of trustees in North Carolina sent their sons to school in Chapel Hill, creating complicated social webs of trustees, their sons, and other students. A close examination of the Bennehan and Cameron families serves to illustrate how intricate these connections could be.

\footnotetext{
58 Wall, "Student Life," pp. 46-47. Wall cautions that the percentages might be higher, since he did not count slaves from second residences.

59 Ibid., pp. 64-65.

60 Trustee circular, 15 April 1837, from the John Caldwell Collection.

${ }^{61}$ UVa Catalogue, 1837-38, pp. 18-19.

62 See, for example, "Agriculture and Manufactures in the South and West," DeBow's Review, vol. 5, no. 2, Feb 1848, pp. 175-191 and "Agriculture and Manufactures in the South and West," DeBow's Review, vol. 5, no. 4, April 1848, pp. 365-390.
}

63 RLD to Family 28 Jan 1840, Dabney Family Papers. 
Richard Bennehan served in the Revolutionary War with William Richardson Davie and joined him on UNC's Board of Trustees in 1799. His son, Thomas Dudley Bennehan, attended both prep school and college in Chapel Hill, graduated in 1801, and became a trustee in 1812. Richard Bennehan's daughter, Rebecca, married Duncan Cameron, trustee from 1802 to 1853, in 1803. Duncan Cameron's brothers, William and John Cameron, attended UNC and, in turn, sent their sons to the University. Duncan's and Rebecca's son, Paul Cameron, was expelled from the preparatory school attached to UNC for fighting in 1825, but he married Anne Ruffin, the daughter of trustee Thomas Ruffin, in 1832. Though not a graduate, Cameron went on to serve as a trustee from 1858 to 1868.64 The web, of course, included many other families. Thomas D. Bennehan's friend Thomas G. Amis wrote to Ebenezer Pettigrew in 1798, "Tho. Bennehan \& all old friends send their compliments to you."65 Ebenezer's father, Charles, was a trustee, and his son, James Johnston, was president of the Dialectic Society. 66 Ties of sonship and marriage bound the trustees and students together in a complex kin network.

Demographic distinctions between faculty and trustees continued to pull students towards the trustees and away from the professors throughout the antebellum period. Board membership remained the exclusive province of native elites. After cataloging the credentials of UVa board members between 1842 and 1861, Philip Alexander Bruce noted that the caliber of officers had not declined from Jefferson's day at all. Citing Congressmen, wealthy merchants, and ministers to foreign courts, he exclaimed, "It was the most prominent single public body in the State; and its exalted quality in ability and

\footnotetext{
64 Passim, Cameron Family Papers \# 133, Southern Historical Collection, Wilson Library, UNC-Chapel Hill. Also, Battle, History of UNC, pp. 221-225. Appendix of Trustees and dates.

65 Thomas G. Amis to Ebenezer Pettigrew, 15 June 1798, Pettigrew Family Papers \#592, Southern Historical Collection, Wilson Library, UNC-Chapel Hill.

66 Passim, Pettigrew Family Papers.
} 
character was maintained with jealous and exacting scrupulousness." 67 The method of selecting trustees ensured that only politically well connected men would serve. In North Carolina, the Trustees themselves filled vacancies until 1804, when the General Assembly took charge. Even though legislators increased the size of the board to 65 in 1821 , they had no difficulty stocking it with qualified men. The governor was always amongst them, for he joined ex officio member after 1805.68 The governor appointed all of the Visitors in Virginia, seven until 1852 and nine thereafter, quite a select group. ${ }^{69}$ Although the trustees of each school continued to hire most faculty from the North or from overseas throughout the antebellum period, they did manage to hire a few native-born scholars. An 1822 letter from Joseph Caldwell, president of the faculty at UNC, to an unnamed trustee exposed how difficult it was to hire out of North Carolina or Virginia. The Trustees had announced an opening for a professorship in languages early in the year, and Caldwell enumerated the names of the top two tiers of candidates: "Mr Andrews of Berlin in Connecticut, Mr. Tyler of Trenton in New Jersey, Mr. Bascome of Massachusetts but then at Charleston, and Mr. Carnahan in the District of Columbia ... Messrs. Rogers of Hillsborough, Leary of Baltimore, and Bruce of Virginia but originally Scotland." 70 Perhaps in their exuberance at finding a qualified candidate from North Carolina, a small committee of the Trustees, including the Governor, had offered Rogers the job without even looking at the other applications, and Caldwell wrote to smooth out the resultant conflict. UVa had more success, and the Visitors hired Gessner Harrison, of

\footnotetext{
${ }^{67}$ Bruce, History of the University, vol. III, p. 138.

6818 Dec 1805 , From the Faculty Affairs: Faculty Minutes, in University Archives, Wilson Library, UNCChapel Hill. Battle, History of UNC, pp. 279-280.

${ }^{69}$ Knight, Documentary History, p. 411 , footnote 7.

${ }^{70}$ From Joseph Caldwell to ?, 20 April 1822, Joseph Caldwell Papers \# 127, Southern Historical Collection, Wilson Library, UNC-Chapel Hill.
} 
Harrisonburg, and John A. G. Davis, of Middlesex County, in 1828 and $1830 . .^{71}$ Despite the visitor's greater success in hiring native Virgininas, only at UNC was there any instance of crossover in membership between the trustees and faculty. There, the General Assembly elected three faculty members to serve as Trustees. These three men, however, were exceptional. In addition to teaching a specific subject in the classroom, all three also acted as presidents of the University: Joseph Caldwell (1804-1812, 1817-1835), Robert Chapman (1812-1817), and David Swain (1831-1868). At UVa, Law professors most firmly planted their feet in both worlds. In the days before academic lawyers, legal experts demonstrated their acumen exclusively by performance in the public sphere. Thus, professors were necessarily influential public men. John Lomax (1826-1830) resigned after a unanimous vote of the Virginia Legislature made him a Circuit Court Justice, and James P. Holcombe (1851-1861) left his post for service in the Confederate Congress. ${ }^{72}$ With few exceptions, then, the trustees and the faculty remained distinctive groups throughout the antebellum period, and students felt social ties to the trustees.

Regardless of their social distance from the students, faculty members gained an increasing amount of influence over their lives. Trustees passed responsibility for discipline over to the professors within years after the arrival of the first students. Though they maintained final say in cases of expulsion, trustees quickly decided that the day-to-day maintenance of order was beyond their capabilities. The professionalization of academic life and specialization within disciplines, especially in the sciences, brought to the faculty additional areas of control in the late 1820s. Professors explored

\footnotetext{
${ }^{71}$ Martin, "John A. G. Davis," pp. 4-26. George Tucker, Professor of Moral Philosophy from 1825 to 1845 was a virtual Virginian. He attended school at William and Mary and served three terms in the U.S. Congress, though he was born in Bermuda.

72 John A. G. Davis (1830-1840) was murdered; H. St. George Tucker (1841-1845) retired at an old age, after having served in the US Congress, VA Senate, and as Chancellor of the States; and John B. Minor (1845-1895) died on the job. Biographies from Barringer, Garnett, and Page, University of Virginia.
} 
increasingly complex avenues of scientific inquiry and cultivated a type of expertise beyond the general knowledge of the legislators, bankers, and planters on the trustee boards. Trustees granted to faculty members increasing authority over the curriculum, grades, and even degrees. Thus, while trustees continued to invest in the extracurriculum, professors carved out a parallel educational track in the lecture halls. There, they taught scholarship, not leadership. Most students resisted this alternative to political education. Never well behaved, they filled the 1830s, 1840s, and 1850s with violent protests against the faculty. By the ferocity of their attacks on professors and the small numbers who actually earned degrees, young men sent the clear signal that they preferred to learn what the trustees had to teach.

Trustees in neither Chapel Hill nor Charlottesville prepared themselves to deal with the level of disorder that students brought to their universities, and they shifted disciplinary responsibility to the faculty as soon as they ascertained what a gargantuan task that maintaining harmony could be. The trustees did not prepare adequate regulations or systems of supervision before the students arrived, and they wrote professors into their revised standards within. a few months of first day of school. Persistent student disorder, surging especially as the faculty acquired more control over the classroom, only encouraged board members to confirm professors' disciplinary prerogatives.

Students at the University of North Carolina invented novel ways to aggravate their professors, and their wretched behavior translated immediately into more restrictive regulations. After only a year of life in Chapel Hill, Professor Ker offered his resignation on July 11, 1796. He left the Trustees a letter, "containing a representation of some disorders among the students in the University \& of the propriety of additional regulations for the institution." In an emergency meeting two days later, the Trustees 
passed a resolution to keep student rooms clean, a curious act following on the heels of a resignation. ${ }^{73}$ Early in 1799, Thomas Hart Benton, the future United States Senator from Missouri, and his friend Archibald Lytle fired pistols at one another in a heated and public exchange. ${ }^{74}$ In March of that year, Benton again disturbed the peace, and his fellow students reported him for stealing from them. ${ }^{75}$ Perhaps in response to these incidents, the Trustees passed a resolution in July that "the Faculty be required to check on students in the morning and evening."76 Fifty-five students, either coerced or voluntarily, then signed a memorial acknowledging that they would submit to faculty authority. They gave their signed assent to the idea that, "the University itself can no longer exist without a Government, whereby order and regularity will be ensured . . . and enforced by our tutors." 77 Only a couple of years later, in 1802, the young men not only drank, vandalized area homes, fought, and trespassed — traditional sins—but they also placed frogs and toads in a professor's bed, secreted a cow into the dining hall, and turned the wooden staircase to the chapel upside down. ${ }^{78}$ In December 1804, the Trustees clarified the faculty's role as enforcers by compelling the professors, president, and tutors to swear to uphold the laws of the University. ${ }^{79}$ Two years later, another resolution gave the faculty authority to use their judgement to punish offenses not enumerated in the

7311 July 1796, 13 July 1796, Board of Trustees, Trustee Minutes, University Archives, Wilson Library, UNC-Chapel Hill.

${ }^{74}$ No date, Faculty Affairs: Faculty Minutes, University Archives, Wilson Library, UNC-Chapel Hill. The early 1799 date is almost certain because there is dated testimony (19 March 1799) about Thomas Benton being a thief, and because there is another 1799 document in which the students vow to obey faculty authority.

75 Ibid., 19 March 1799.

7612 July 1799, Board of Trustees, Trustee Minutes, University Archives, Wilson Library, UNC-Chapel Hill.

77 Undated, but 1799 or early 1800 because all of the 1800 graduates signed, From the Faculty Affairs: Faculty Minutes, University Archives, Wilson Library, UNC-Chapel Hill.

78 Ibid., 8 Aug 1802 (frogs), 28 May 1802 (cow), 14 June 1802 (steps). 
rules: "The faculty of the University ... are hereby expressly directed, to forbid and prohibit. . . all games, plays and pastimes (sic). . which they may consider as having a tendency to endanger the lives or limbs of the students." 80 Fully aware by this point that the young men whom they hoped to train as leaders had more than a few wild oats, the Trustees relied on the faculty to keep them from hurting themselves, one another, or the University's reputation.

The "blooded colts" at Virginia engaged in similar "deviltries and excesses," and their rebelliousness caused the Board of Visitors to tighten their initially lax disciplinary code tenfold. ${ }^{81}$ In 1825, Jefferson, with a supreme belief in reason, had called for a board of six student censors to adjudicate all offenses with penalties short of expulsion or suspension. Neither students nor faculty liked the system very much. Students hated being responsible for reporting one another's transgressions, and professors complained that no one supervised the censors themselves. ${ }^{82}$ Under these utopian and impractical rules, disorder reigned. On the evening of 1 October 1 1825, Professors John Emmett and George Tucker attempted to break up a gathering of masked students that had caused intermittent disturbances for weeks. As the professors tried to apprehend one of the masked hooligans, others assaulted the two faculty members with bricks and canes. ${ }^{83}$ The following Monday morning, the faculty, incensed, presented two letters: one to the students, demanding that they turn over the perpetrators, and one to the Board of Visitors,

\footnotetext{
79 Ibid., 28 Dec 1804.

${ }^{80}$ Ibid., 6 Dec 1806.

${ }^{81}$ Porte Crayon (David Hunter Strother), Virginia Illustrated: Containing a Visit to the Virginian Canaan, and the Adventures of Porte Crayon and His Cousins (New York: Harper and Bros, 1871) 241 in Knight, Documentary History, p. 372. "It gives me great pleasure to say that, although the vivacity of these blooded colts at our Virginia colleges frequently leads them into all sorts of deviltries and excesses, they have almost invariably the manners of gentlemen." This quotation, unfortunately, is anachronistic here; Crayon made his trip in 1853.

82 Wall, "Student Life," pp. 149-150.

${ }^{83}$ Bruce, History of the University vol. II, pp. 298-299.
} 
threatening immediate resignation unless they changed the disciplinary code. The Visitors called an assembly of the students, and Jefferson attempted to address them: However, after, "saying that this was the most painful event of his life," the former president "soon became so much affected that he could not proceed." 84 Shamed into confession by the disappointment and tears of their idol, four students admitted guilt and left the school immediately.

The Visitors seized this opportunity to completely rewrite their rules. They met on the following Monday, Tuesday, Wednesday, Thursday, and Friday and scripted a litany of new rules. The Visitors proscribed mandatory uniforms, determined the exact hour of rising, outlawed masks, set minimum punishments for insubordination and drunkenness, and prohibited profanity. They forbade students to even be outside their rooms at night without permission. Furthermore, they ordered 400 more copies of the new Enactments printed up and established a committee to look into the possibility of bringing a criminal court on grounds in order to try students more swiftly. ${ }^{85}$ The Board of Visitors not only passed these regulations, but they also empowered and exhorted the faculty to enforce them. "The Professors being charged with the execution of the laws of the University," they intoned, "it becomes their duty to pursue proper means to discover and prevent offences." 86 From then on, the faculty became the enforcers. The American Quarterly Review reported in 1831 that at UVa, "there is an entire separation of the

\footnotetext{
${ }^{84}$ Address of Henry Tutwiler, LL. D., of Alabama, before Alumni Society, 29 June 1882, in Patton, Jefferson, Cabell, and the University, pp. 132-133.

85 UVa, BOV Minutes, vol. II 1817-1836, 3-7 October 1825.

${ }^{86}$ UVA, BOV Minutes, vol. II, 5 October 1825.
} 
legislative from the executive power; the board of visitors exercising the former--the board of professors, or faculty, the latter."87

From the late 1820 s, professors also became the enforcers in the classroom. Both the UNC and UVa trustees planned to give final examinations themselves, but increased specialization in the classroom cut into their ability to do so effectively, and they allowed the professors to determine grades and class rank. On the level of the individual school, the multiplication of professorships, particularly in the sciences, indicated specialization. ${ }^{88}$ There were additional signs on the national level; faculty members could display specialized knowledge by publishing research in new technical journals or by attending the meetings of new professional associations. Scholars from both schools joined the American Association for the Advancement of Science, the first broad-based professional organization for American scientists (founded in 1848). ${ }^{89}$ The proliferation of specialized literature also led trustees to give instructors control over acquisitions for the library. The faculty at Southern state universities made their classrooms gateways into a larger scholastic world.

As Professor of Mathematics and Astronomy in 1796, Joseph Caldwell held the only science-oriented position on the faculty at UNC. In 1822, by which time Caldwell had become President of the University, three of the five faculty members were "scientists:" Caldwell as Professor of Mathematics and Astronomy, James Phillips as

87 "Joumal of the Proceedings of a Convention of Literary and Scientific Gentlemen, held in the Common Council Chamber of the City of New York, October 1830," June, 1831, pp. 283-314. Quotation from p. 292.

88 Daniels, "The Process of Professionalization in American Science," p. 154. Daniels charted the splintering of natural philosophy into many sub-fields by examining the articles from Benjamin Silliman's American Journal of Science and the Arts, first published in 1818. Chemistry as a distinct field emerged in 1818 , geology in the 1820 s, zoology in the 1830 s, botany and mineralogy in the 1840s.

${ }^{89}$ Kohlstedt, The Formation of the American Scientific Community, appendix. Kohlstedt cataloged every member of the society from 1848-1860. Elisha Mitchell, Denison Olmsted, and Alexander Fisher Olmsted from UNC and William Barton Rogers, Robert E. Rogers, and John Lawrence Smith from UVa, for example, were all members. The AAAS grew out of the Association of American Geologists and Naturalists, an organization built around the two earliest specializations. 
Professor of Chemistry and Moral Philosophy, and Elisha Mitchell as Professor of Chemistry, Geology, and Mineralogy. ${ }^{9}$ Mitchell, as his colleague Denison Olmsted had done, demonstrated his scholastic prowess by publishing several articles in Yale Professor Benjamin Silliman's magazine, the American Journal of Science and Arts. As additional proof of the growing importance of science in Chapel Hill, Caldwell started construction on the nation's first University observatory in 1830.91 After Caldwell's death, the telescope crumbled with neglect, but professors at the University continued to teach specialized topics. The Trustees created two additional professorships, Charles Phillips in Civil Engineering and Benjamin Hedrick in Agricultural Chemistry, as a part of the planned School for the Application of Science to the Arts in 1852. Through this school, which opened in 1854 , the Trustees attempted to connect the sciences to basic concerns of the elite, including transportation and farming. .92

The Board of Visitors at UVa also endorsed specialization in the name of practicality. Jefferson intended to offer "mathematical and physical sciences" in order to "advance the arts, and administer to the health, the subsistence, and the comforts of human life," with little interest in raw research. 93 The increase in science professorships followed this practical curve. To the four initial science-oriented professorshipsMathematics, Natural Philosophy, Medicine, and Chemistry/Materia Medica-the Visitors added specialists to address specific, concrete problems. In 1831, for example,

90 Thomas Kevin Cherry, "Science at the University of North Carolina, 1795-1853," MA Thesis, UNC, 1993, pp. 55-65. I used "scientist" in quotations, because William Whewell, an Englishmen, did not coin the term until 1840. Sally Kohnstedt, The Formation of the American Scientific Community: The American Association for the Advancement of Science, 1848-1860 (Urbana: University of Illinois Press, 1976), p. xi.

91 Waldo Haisley, "Physics and Astronomy at Chapel Hill, 1795-1946" (Chapel Hill: [UNC], [1989?]), pp. 2-3. Battle, History of UNC, pp. 334-335.

9229 June 1837 first mention, 29 Dec 1852 decision, Board of Trustees: Executive Committee Minutes, University Archives, Wilson Library, UNC-Chapel Hill.

93 "Report of the Rockfish Gap Commission," Knight, Documentary History, p. 165. 
Thomas Johnson joined the faculty to focus on anatomy. The school added yet another medical position in 1849, when James L. Cabell (the trustee's nephew) arrived as Professor of Comparative Anatomy, Physiology, and Surgery. ${ }^{94}$ Without hiring a new professor, the Visitors also instituted a School of Engineering in 1837.95 This structural addition did not come alive after the Civil War, when three new professors arrived, in Applied Mathematics and Engineering, Applied Chemistry, and Natural History/Agriculture. ${ }^{96}$ The number of professorships climbed with specialization.

Like Mitchell and Olmsted had done in Chapel Hill, UVa specialists achieved notoriety in the scientific world that augmented their confidence in the lecture hall. John Emmet, a chemist, published at least five times in Silliman's journal. Charles Bonnycastle and Robley Dunglison, for their part, published national textbooks in their respective fields, Natural Philosophy and Medicine. ${ }^{97}$ In 1848, Professor William Barton Rogers called to order the first meeting of the American Association for the Advancement of Science, the premier professional society. This precocious scholar had served as Chairman of the American Association of Geologists and Naturalists in 1847 before being elected by his fellow scientists to head the American Social Science Association. He eventually left Charlottesville for Boston, the seat of many scientific organizations, and wrote for the Boston Society of Natural History and the American Academy of Arts and Sciences. A little more than a decade later, in 1865, Rogers formally incorporated the Massachusetts Institute of Technology, and his peers elected him its first President. ${ }^{98}$

\footnotetext{
${ }^{94}$ Passim, Semi-centennial Catalogue.

95 UVa Catalogue, 1837-1838, p. 2.

96 Passim, Semi-centennial Catalogue.

${ }^{97}$ Barringer, Garnett, and Page, University of Virginia, pp. 346-348. Biographies.

98 Ibid. 352-353. Biographies.
} 
The specialization of knowledge gave the professors more control over the granting of degrees. Years before the University of North Carolina even accepted its first student the Trustees planned to examine personally all potential graduates. ${ }^{99}$ Trustees held these examinations publicly at Commencement, which offered a double opportunity for students to network with the elite. Not only could they introduce themselves to the state's most distinguished men, but they could also demonstrate their erudition in front of potential employers. In 1809, the Trustees further dictated that "each of the four standing classes of students in the establishment" be examined every year. ${ }^{100}$

Trustees felt increasingly uncomfortable administering oral tests on subjects that they had never studied, and they yielded to the judgement of the faculty, who knew the material. During the 1830 s in Chapel Hill, written tests administered by the faculty displaced oral exams by the Trustees. In response to critiques from the faculty on their ability to test effectively, Trustees had tightened the examination procedure in 1832 by naming a rotating panel of Trustees to deal with the examinations. ${ }^{101}$ The delineation of responsibility did not resolve the problem of lack of trustee expertise, and they passed the privilege of examination to the faculty. Perhaps because Jefferson alone of the Visitors had been capable of examining students in each of UVa's eight, Virginia dropped its policy of oral examination as soon as he died. As George Daniels has suggested, even Jefferson would probably not have been able to keep up with pace of specialization after 1840.102 From 1826, the UVa professors followed an "English model" and administered written examinations in all subjects, graded by a committee of three faculty members.

\footnotetext{
9921 Dec 1793, 8 Dec 1795, and 10 July 1799 From Board of Trustees: Trustee Minutes, University Archives, Wilson Library, UNC-Chapel Hill.

100 Ibid., 13 Dec 1809.

${ }^{101}$ Battle, History of UNC, pp. 364-365.

102 Daniels, "The Process of Professionalization," p. 151.
} 
The Board of Visitors preserved some measure of oversight and made it a policy to review each faculty decision before officially passing or failing a student. ${ }^{103}$ In order to compensate for the loss of the public spectacle that oral exams provided, Board Members published the names of the top quartile of students in the state's biggest papers. ${ }^{104}$ This ensured that at least a few students would have the pleasure of having their name widely circulated around the state. Control over grades also granted faculty the ability to choose valedictorians, those honor students who presented orations on the commencement holiday.

The first report cards made students at UNC painfully aware of the faculty's dominant role the classroom. By 1826, the Trustees instituted a system of standardized disciplinary reporting that gave the faculty tremendous control over the development and grading of the students. Twice a year, professors sent out a letter to the parents of every student. In this form letter, they listed the total number of students enrolled in the University, the number of students who had missed prayer or recitation, and the exact number of times that the particular student had missed prayers, divine worship, and recitation. The faculty also included a brief, subjective comment on the quality of the student's scholarship, with terms such as "good," "respectable," "tolerable," "very good," etc. ${ }^{105}$ Based on this data the faculty also compiled a merit roll, on which they listed particularly delinquent students. In October 1839, for example, John R. Caldwell was "recorded on the Merit Roll once for irreverence at Prayers and four times for other

\footnotetext{
103 “Proceedings of a Convention," p. 312.

104 UVa Catalogue, 1837-1838, p. 17.

105 Battle, History of UNC, p. 314. Trustee circulars, John Caldwell Papers \#127, Southern Historical Collection, Wilson Library, UNC-Chapel Hill.
} 
improprieties." The faculty warned, "His application is not believed to do justice to his opportunities." 106

Students such as John Caldwell lashed out against faculty in protest of the new academic standards, from the 1830s throughout the antebellum period. By their actions, students showed that they had come to school to make connections with and learn from the trustees-not to earn straight "very goods" on their report cards. They paid very serious attention to social events and to the literary societies but often acted violently against professors. Every punch thrown or insult hurled against a professor indicated a student's choice for extracurricular education.

At UNC, students verbally and physically abused faculty members and refused to attend lecture. UVa students behaved in an equally deplorable manner, severely beating the chair of the faculty senate and engaging in fisticuffs over the slightest offense to their honor, even by faculty members. In 1839, a group of angry students beat Professor Bonnycastle after he attempted to rescue a slave from abusive UVa students. Angry students attacked even native Virginian professors. In 1830, the day after Professor Gessner Harrison had rebuked a student publicly, that student punched him in the face and whipped him with a horsewhip, in front of a crowd of over 200.107 A less volatile young man, Robert Lewis Dabney, did not raise his fist in anger but clearly articulated the disdain that students felt for the foreign faculty. In 1840, he complained " $\mathrm{He}[\mathrm{Mr}$. Rogers] has the manners of a Virginian too, while the other two are English cockneys (Bonnycastle \& Emmet), and their manners are more unsuited to my tast[e] than the manners of the yankees." 108 In Chapel Hill, one rebellious student revealed the depth of

\footnotetext{
106 Trustee circular, 4 October 1839 , ibid.

107 Bruce, History of the University, vol. II, pp. 292-293.

108 RLD to Charles W. Dabney, 16 Jan 1840, from Papers of the Dabney Family MSS 38-219, Special Collections, UVa Library.
} 
his scorn in a poorly phrased apology to a tutor. He wrote with attempted sincerity:

"My intention in throwing the rock at the window of the room in which you was wasn't to injure you or either of the Faculty but rather to irritate and perplex you. Nor had I any other motive than endeavoring to insult. . .."109 John Perry of UNC summarized student animosity towards their professors in 1839 , "Daily observation proves to me, that the Faculty are a set of rascals." 110

Two of Dabney's classmates at UVa, Joseph Semmes and William Kincaid, committed the most atrocious act of rebellion in 1840. They armed themselves, put on masks, and walked towards Pavilion X, where they had heard that Professor Davis, beloved by many, was waiting for them. Semmes and Kincaid shook hands with a large group of students assembled on the Lawn before they went, badmouthing the professors. One observer remembered their taunts, that "they said they cared not for Davis." They went to the beloved Law Professor's home, where he commanded them to take off their masks. Apparently they had had too much of faculty control, and they shot and killed him instead of complying. ${ }^{111}$ Rebellion in Charlottesville extended even to the slaughter of a favorite professor.

The faculty at both schools undeniably accumulated new responsibilities during the antebellum period, responsibilities that often infuriated students. They could punish the young men, decide what to teach them, and grant them important awards. All of this, however, did not give them control over the students' dreams. Few young men attended the state schools in the hope of gaining scientific renown or cultivating lasting relationships with their professors. Rather, the "blooded colts" at UVa and UNC strove

109 UNC, Faculty Minutes, John Allen to Faculty, 27 June 1810 (letter enclosed).

110 From John Perry to Father, 18 May 1839, in the University Letters-UNC Papers \# 3129, Southern Historical Collection, Wilson Library, UNC-Chapel Hill.

${ }^{111}$ Hunter H. Marshall to William Cabell Carrington, MSS - 7069, Special Collections, Alderman Library. 
to emulate the trustees, who maintained ultimate control of the Southern state universities through their role in the extracurriculum.

The trustees continued to exert a defining influence on students primarily through personal contact. In addition to sending their children to the state universities, which created strong bonds among leading families, the trustees and students met together at designated times throughout the school year. The student literary societies organized most of these activities, including balls, speeches, and festivities surrounding commencement day. Students in the literary societies modeled themselves after the trustees: they wrote letters to them, commemorated their achievements as a body, and practiced their own statesmanship on the friendly confines of the university campus. Board members encouraged this relationship by providing for a place for the societies to meet, resolving disputes among members, contributing to their projects, and appearing at their functions. Through the extracurriculum, trustees demonstrated to students the gracious conduct and rhetorical skill required of state leaders and built personal connections. Thus the trustees accomplished their goal of raising up state leaders.

Though a terrible fire in 1895 destroyed many records of the various literary societies at the University of Virginia, the societies at North Carolina kept excellent records that are well preserved. From the available evidence, though, it is clear a majority of students at each university joined literary societies early on. Students in Chapel Hill formed the Dialectic and Philanthropic Societies in 1795, though they did not give the organizations Greek names until 1796.112 These two societies competed for prestige and for the attention of the trustees throughout the antebellum period. Though a brief history enclosed within the Dialectic Society papers suggests that membership in

112 Storie, "The American College Society Library and the College Library," p. 247. Battle, History of UNC, pp. 72-77. 
one of the two groups was mandatory, there is little corroborating evidence for this assertion. Students could leave the Societies, as William Davie's son, Hyder, did in 1804. Furthermore, the Philanthropic and Dialectic Societies agreed to certain restrictions on membership themselves. In 1805, they decided that no member of the preparatory school adjacent to the University could become a member, and in 1815 they confirmed an earlier agreement that students needed to live in Chapel Hill for 5 weeks before they could even be considered for membership. ${ }^{113}$ Even if membership was not universal, however, the vast majority of students clearly joined one of the two groups. The combined membership totaled over thirty in 1795 , when there were seldom more than that number at the University. At least two-thirds of the student body probably belonged to one of the two societies at any given time.

About the same percentage of students probably joined literary societies at the University of Virginia. In Charlottesville, students founded the Jefferson Society in the school's first year and the Washington society in the $1835-1836$ session. Unlike students in North Carolina, however, the Virginians constantly experimented with a third Society: the Patrick Henry, Philomathean, Columbian, and Academic Societies, for example. ${ }^{114}$ Henry C. Allen, a student in 1855 , explained that the $\$ 10$ membership fee kept many members out of the Jefferson Society, though the group still claimed over 100 members. Given roughly equal numbers for the competitive Washington Society, along with a rival

\footnotetext{
113 Nothing in the Trustee record suggests mandatory membership. Hyder Davie to Dialectic Society [1804]. Davie left the group after six years in it, which suggests that his undated correspondence is from 1804. Dialectic Society Minutes, 7 March 1815 for 1815 resolution. From the Student Organizations and Activities: Dialectic Society Records in University Archives, Wilson Library, UNC-Chapel Hill. Also, Thomas D. Bennehan to W. [B. Miares] 16 Aug 1805 in Cameron Family Papers.

114 Patton, Jefferson, Cabell, and the University, pp. 245-247. The Patrick Henry Society was actually the parent society of the Jefferson Society, though it maintained a distinct identity until at least 1829 . An 1849 invitation from the Philomathean Society can be found in the papers of the Dialectic Society. From the Student Organizations and Activities: Dialectic Society Records in University Archives, Wilson Library, UNC-Chapel Hill. 1 Feb 1855, Henry C. Allen to John J. Allen from Papers of the Allen Family MSS 9780, Special Collections, UVa Library.
} 
third society, "which [was] doing well," it seems that over half of the students at UVa participated in society life. ${ }^{115}$

The trustees sought to encourage membership by providing a meeting place for the societies. Virginia's Board of Visitors initially shuffled the Societies into unused space, as they did to the Jefferson Society in 1827, Patrick Henry Society in 1829, and Academic Society in 1833.116 Whenever the academic demands of the University demanded that the Visitors reclaim their space, they sought to provide alternative venues. In July of 1831, they Visitors forwarded a request for from the Jefferson Society for more space to the Executive Committee, which was "required to extend to the Society such accommodations as may be found practicable."117 The Visitors eventually granted to the Jefferson Society the control of Hotel C, a large hall located along the west side of the original academical village. In North Carolina, trustees also accommodated the students' need for a meeting place. When there were not enough available buildings early on, they let the Societies meet in the Chapel, and even set up a "stage for public speaking" there. ${ }^{18}$ With the help of the University, the Societies built their own spaces for a time, but the Trustees helped them raise money for a nicer hall in the mid-1840s. ${ }^{119}$

The Trustees and Visitors attempted to preserve harmony among the various societies. Jefferson, for example, refused to accept an offer of honorary membership in the Jefferson Society out of fear that he would appear partial to one group over another. Nonetheless, the third president rewarded the sentiments of the Society with a kind letter and explained to the invitation committee, "Your kind expressions toward myself ensure

\footnotetext{
1151 Feb 1855, Henry C. Allen to John J. Allen, Papers of the Allen Family.

116 UVa, BOV Minutes, Volumes I and II, 18 July 1827, 20 July 1829, 17 July 1833.

117 UVa, BOV Minutes, Volume II, 18 July 1831.

118 UNC, Trustee Minutes, 12 Dec 1810.

119 UNC, Executive Committee Minutes, 16 Oct 1843.
} 
to me, I hope, an equally kind acceptance of the reasons on which I act."120 The

Visitors also took the extreme step of policing student speeches in 1828, after members of one society made particularly invective remarks. Though there is no formal repeal of the measure requesting that faculty censure all harmful speech, the practice certainly did not continue for more than a year or two. ${ }^{121}$ The North Carolina Trustees intervened on one very traumatic occasion, in 1838. Then, a few students seceded from the Dialectic Society and attempted to form their own literary club. The Dialectic Society formally appealed to the Trustees for help and requested that a committee of Gov. Dudley, Gov. Swain, Judge Cameron, Judge Ruffin, Charles Manly, and Rev. McPheeters adjudicate their dilemma. The Executive Committee agreed that the quick resolution of the problem was "highly important to the best interests of the College" and sent the requested committee to resolve the problem. A more august tribunal could not be found within the highest echelons of North Carolina politics — the secessionists returned. 122

A steady stream of letters between the trustees and the student members of the literary societies both deepened relationships between the two groups and exposed the students to the elegant art of political communication. Students wrote trustees in order to recognize them with honorary membership, invite them to speak, solicit money from them, or involve them in their society's events. Such high level correspondence seemed commonplace to some student leaders; on 20 January 1841, William Mullins, president of a UNC society, casually recorded in his diary, "read several letters of Wm. R. Thing (sic, but probably King), Will. Gaston, Tom. B. Sheppard, and other less distinguished, to our

\footnotetext{
120 Patton, Jefferson, Cabell, and the University, p. 239-240.

121 UVa, BOV Minutes, 4 Oct 1828.

122 UNC, Executive Committee Minutes, 7 Jan 1839. Letter from the Dialectic Society to the Executive Committee, 4 Dec 1838. Found in Student Organizations and Activities: Dialectic Society Records in University Archives, Wilson Library, UNC-Chapel Hill.
} 
Society."123 Gaston was a longtime trustee and NC Supreme Court Justice, King a future Vice-President of the United States. Sometimes students simply wrote to the trustees for help. In dire financial straits, Charles L. Mosby of the University of Virginia contacted General John H. Cocke, a member of the Board of Visitors. He begged the general for assistance, and Cocke provided the funds for him to attend three sessions at the University. Cocke's investment in the young man's future paid dividends; in 1865, Mosby joined the Board of Visitors. ${ }^{124}$ Frequent letters both established paths for patronage and taught students how to write persuasively and courteously.

Trustees and students watched one another perform more directly at the annual commencement exercises. The oration carried the day at these events, and both students and trustees addressed those gathered for the festivities. Originally, the trustees designated the student orators, but that task passed to the faculty, who had gained almost exclusive responsibility for evaluating student classroom performance. The speakers at commencement were not all academic, however. The literary and debating societies at each school nominated several individuals to speak, including students and well-known community members, often trustees. ${ }^{125}$ Although students spoke at sundry other occasions throughout the year, including Independence Day and Washington's Birthday, the commencement speeches offered a unique opportunity to impress the best men of the state. ${ }^{126}$ Kemp Battle, himself a UNC trustee later in life, hoped that his 1849 valedictory address would earn him a job with the railroad: "I applied to ex-Governor

123 Center for the Study of the American South, IRSS Faculty Working Group in Southern Studies. Two Hundred Years of Student Life at Chapel Hill: Selected Letters and Diaries, ed. Lisa Tolbert, intro. James Leloudis (Chapel Hill: Fall 1993), p. 43.

124 Wall, "Student Life," p. 61. Passim, Semi-centennial Catalogue.

125 In Chapel Hill, from 1827 on, the societies took turns selecting a well-known public figure to deliver a message to a joint gathering of the groups. Battle, History of UNC, p. 315. At UVa, the literary societies nominated two students to deliver final addresses - the current president of the society and the valedictorian. Patton, Jefferson, Cabell, and the University, pp. 241, 360-368.

${ }^{126}$ Barringer, Garnett, and Page, University of Virginia, p. 166. 
Morehead, president of the company, for a situation as rodman and hoped that, as he was present as a trustee when my Commencement honors were won, I might gain the humble post." Morehead granted him a supervisory position, but Battle turned it down. ${ }^{127}$ The orations could be beneficial to adults as well; James B. Shepard, class of 1834 claimed that a well-received speech before the UNC societies contributed to his decision to run for Governor. He lost to William A. Graham, a trustee. ${ }^{128}$ The oration continued to be such an important part of the final program that, in 1857, the Virginia Societies began awarding a debater's medal to the best orator. The introduction of prizes underscored the competitiveness of such events. Like speeches in the state house and elsewhere, word choice and presentation mattered.

Certainly at UNC and probably at UVa, the trustees helped the debating societies in a more direct way by helping to fund society libraries. ${ }^{129}$ At UNC, the combined size of the society libraries equaled or surpassed the size of the school's official collection through the 1850s. ${ }^{130}$ The Rotunda fire of 1895 destroyed records of the Washington and Jefferson Societies' holdings, but their collection almost certainly did not outnumber the several-thousand volume collection that Jefferson had first established. Judging primarily from data collected on the UNC libraries, other society libraries throughout the South, and from anecdotal evidence at UVa, the society libraries contained books that complemented, rather than paralleled the school library. For example, English language fiction, periodicals, and travel narratives abounded in society libraries, while the University Libraries contained mostly foreign language books, including Latin and Greek

\footnotetext{
${ }^{127}$ Kemp Battle, Memories of an Old Time Tar Heel, ed. William J. Battle (Chapel Hill: UNC Press, 1945), p. 79.

${ }^{128}$ Battle, History of UNC, pp. 483-484.

129 Albert and Gladys Hall Coates, The Story of Student Government in the University of North Carolina at Chapel Hill (USA: Albert and Gladys Hall Coates, 1985), p. 46.
} 
classics as well as modern French and German manuals. ${ }^{131}$ The literary society

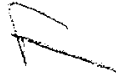
members kept their libraries open for longer hours and lent books to students on a much more frequent basis than did the University libraries. The type of books in these libraries, with the emphasis on English-language works, especially poetry and English literature, suggests that the students agreed with the trustees that real influence lay in the manipulation of the English language, not in the study of chemistry or mathematics.

Students decorated their meeting rooms with items that indicated the almost hypnotic sway that the trustees held over them. Albert and Gladys Hall Coates have cataloged twenty-six portraits belonging to the Dialectic or Philanthropic Societies at UNC. Trustees are the subject of the majority of these portraits, seventeen out of twentyeight. ${ }^{132}$ The Dialectic Society celebrated these images in a fundraising letter from the 1830s: "from the walls hang portraits of various State worthies, like guardian Genii of the place, looking with complacency on the efforts of the young hope of the state."133 The students themselves paid for these portraits and spent staggering amounts of their own money to solicit the best painters. Charles Wilson Peale, for example, painted a portrait of Davie at the expense of the combined UNC societies. Trustees Archibald Murphey and Thomas Ruffin, among others, also sat for the Dialectic Society. ${ }^{134}$ The Jefferson Society in Virginia collected portraits of its own during the antebellum period, the most famous of which was a Thomas Sully portrait of Jefferson. ${ }^{135}$ A larger version of the Sully

\footnotetext{
130 Storie, "The American College Society Library and the College Library," p. 242.

131 McLachlan, "The Choice of Hercules," pp. 478-480.

132 Coates, The Story of Student Government, pp. 50-56.

133 183? Circular, Found in Student Organizations and Activities: Dialectic Society Records in University Archives, Wilson Library, UNC-Chapel Hill.
}

${ }^{134}$ Minutes 20 Mar 1829 and 30 Sept 1840, Found in Student Organizations and Activities: Dialectic Society Records in University Archives, Wilson Library, UNC-Chapel Hill.

135 This portrait now hangs in the "President's Reception Room" on the second floor of the Rotunda, on loan to the University from the Jefferson Society. 
portrait still hangs in the nation's capital, perhaps the best-recorded likeness of Jefferson. These icons of greatness reminded the students of their goals-specifically of the importance of building an honorable reputation.

The trustees successfully attracted the South's finest young men into the service of their state and region. Of the twenty-one final antebellum presidents of the Jefferson Society, five served in the state legislature, one as president of Richmond College, another as Commonwealth Attorney, one as Robert E. Lee's personal assistant, and another as editor of a Richmond paper. ${ }^{136}$ For students from UNC, the transition from student to state leaders seemed almost automatic. The overachieving class of 1818 included James K. Polk, President of the Dialectic Society and of the United States of America; William Green, Bishop of Missouri and Chancellor of Sewanee; Robert Morrison, President of Davidson College; Hamilton Jones, editor and Supreme Court justice; Hugh Waddell, President of the State Senate; and William Moseley, Speaker of the State Senate and later Governor of Florida. ${ }^{137}$ Trustees often helped facilitate these career moves. William H. Battle informed Thomas Ruffin, a fellow trustee, about the suitability of Robert Fuller for a legal post; "Mr. Fuller was graduated at our University in June 1844, and while in College he acquired a high character for regularity, diligence, and gentlemanly demeanor."138 Between 1810 and 1899, 60 percent of North Carolina's Governors had graduate from the University.

Graduates of the state universities also led their states through the secession crisis and through civil war. At Virginia's secession convention, 38 of 152 delegates had

\footnotetext{
136 Patton, Jefferson, Cabell, and the University, list of presidents p. 360. Semi-centennial Cataloge, passim.

137 Battle, History of UNC, p. 258.

138 William H. Battle to Thomas Ruffin, 24 Dec 1845, Thomas Ruffin Papers \# 641, Southern Historical Collection, Wilson Library, UNC-Chapel Hill.
} 
graduated from UVa. The percentages were even more extreme in North Carolina; there, 51 of 147 had graduated from UNC. ${ }^{139}$ At least five UVa alumni served on Jefferson Davis' cabinet during the war: Robert Toombs, Robert M. T. Hunter, George Randolph, Thomas Watts, and James Seddon. The bullets and disease of the Civil War prevented hundreds of other graduates from ever holding office. 488 of the 9,000 men who had spent some time at UVa died during the war, 271 of the 1,904 alumni from UNC who fought also gave their lives. ${ }^{140}$

Despite the volume of men that marched forth to war through the gates of Southern universities, no deficiency in their curriculum or agrarian orientation necessarily engendered regional animosity. In fact, students at the best Southern and Northern universities received almost identical educations before the war. Students at Yale, the University of Pennsylvania, and the College of New Jersey also heard sophisticated lessons in science from their professors and gathered together in literary societies to emulate their trustees. Yale's Brothers in Unity and Linonian Societies, and the College of New Jersey's American Whig and Cliosophic Societies sent even more men into public life than did the societies of their Southern counterparts. ${ }^{141}$ Students in both regions rebelled against faculty authority, got drunk, and sought the most prominent public positions. The Universities of North Carolina and Virginia did not engender sectional hatred because of the faculty's educational track-because of the curriculum; they were members of an elite group of national colleges. Nor, for that matter, did the trustees intend to spread sectionalist venom. They sought to introduce their students into public life within the state and introduced them into a political world radiating out from

\footnotetext{
139 John Gilchrist McCormick, "Personnel of the Convention of 1861," James Sprunt Historical Monographs, No. 1 (Chapel Hill: UNC Press, 1900), p. 9. Patton, Jefferson, Cabell, and the University, p. 359.

140 Patton, Jefferson, Cabell, and the University, pp. 218, 222-233. Battle, History of UNC, pp. 749-750.

${ }^{141}$ Harding, College Literary Societies, p. 20.
} 
Raleigh and Richmond, touching only lightly the rest of the South. Southern students thus had a comparable academic education to their Northern peers, but they graduated into a trustee-dominated political universe where the state loomed all important. 


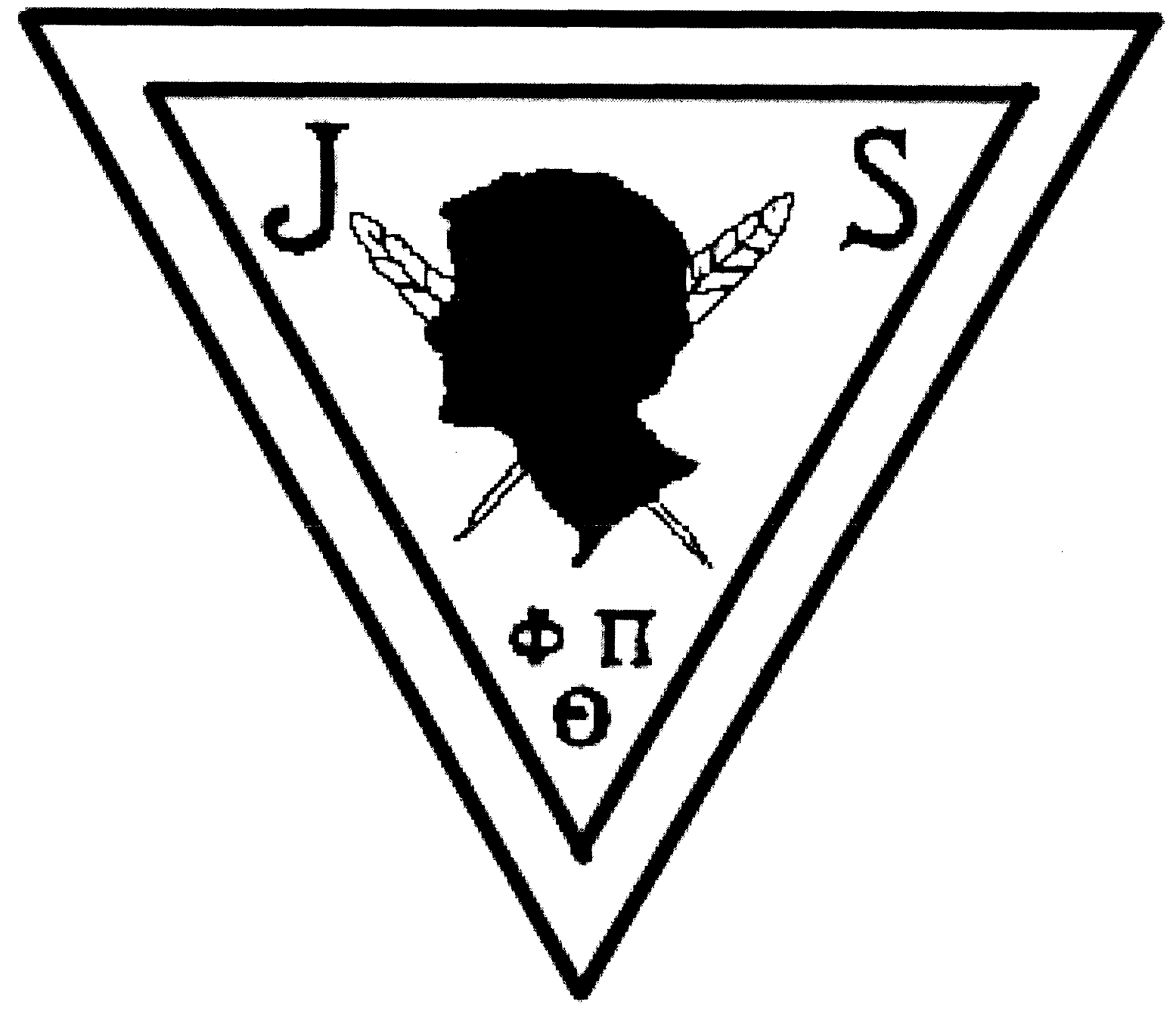

